\title{
The Effectiveness of Multimedia Learning on Academic Achievement in Reproduction Topic Science Subject
}

\author{
Teo Yang Kiat ${ }^{1, *}$, Jumintono ${ }^{1}$, Erwin Setyo Kriswanto ${ }^{2}$, Sugiri $^{3}$, Etty Handayani ${ }^{4}$, Yunita Anggarini ${ }^{5}$, \\ Mochamad Rofik ${ }^{6}$ \\ ${ }^{1}$ Faculty of Technical and Vocational Education, Universiti Tun Hussein Onn Malaysia, Malaysia \\ ${ }^{2}$ Faculty of Sport Science, Universitas Negeri Yogyakarta, Indonesia \\ ${ }^{3}$ Department of Aeronautics, Sekolah Tinggi Teknologi Kedirgantaraan Yogyakarta, Indonesia \\ ${ }^{4}$ Faculty of Agriculture, Universitas Muhammadiyah Yogyakarta, Indonesia \\ ${ }^{5}$ Department of Teknologi Bank Darah, Politeknik AKBARA Surakarta, Indonesia \\ ${ }^{6}$ Academy of Management Administration Yogyakarta (Ama Yogyakarta), Yogyakarta, Indonesia
}

Received May 12, 2020; Revised June 13, 2020; Accepted July 20, 2020

Copyright $\odot 2020$ by authors, all rights reserved. Authors agree that this article remains permanently open access under the terms of the Creative Commons Attribution License 4.0 International License

\begin{abstract}
This study aims to evaluate the effectiveness of multimedia-based learning on the academic achievement of science subjects in junior high school students. The method used in this research is descriptive. This study involved 40 junior high school students in Malaysia. The research sample was divided into two groups, namely conventional (control) and experimental (based on multimedia). Data obtained by providing pre-test and post-test to students. Data collected were analysed using descriptive and inferential statistics. A normality test is performed to determine the distribution of data. Data were analysed with a 5\% T-test. The results of the analysis on the pre-test scores indicate that students in conventional and experimental teaching have the same level of knowledge, whereas in the post-test scores there are significant differences between traditional teaching scores and multimedia teaching. The finding of this study also showed that the student-centered learning approach was suitable for learning science subjects for secondary education. Students were found more active in engaging themselves in their learning and contribute to higher academic achievement in the post-test result. In conclusion, the use of multimedia elements in learning materials enables students to learn at their own pace. Through learning with the integration of multimedia-mediated content, student achievement in science subjects is enhanced, and it has helped students to develop a better understanding of science concepts and ideas.
\end{abstract}

Keywords Academic Achievement, Multimedia Learning, Reproduction, Science

\section{Introduction}

Our world had changed in conjunction with the development of Information and Communication Technology (ICT). The development of ICT allows the public to receive information in a more natural, better, and faster way. The integration of ICT in vocational education is very beneficial not only for teachers but also for students [1]. People can receive the information they need anytime and anywhere, and they have a computer or device that is equipped with the Internet $[2,3]$. With the existence of ICT, our society was living in a life composed of electronic technology. Online learning technology is fundamental for educational institutions to develop their online learning systems [4]. The development of ICT in the world had brought transformational changes in numerous fields and careers, including the education field. ICT had been known as an invaluable asset and basic knowledge of 21st-century learning [5]. 21st century ICT skills are defined as the ability to use communication tools and other digital technology to solve any obstacles in the information environment [6]. Ministry of Education Malaysia had acknowledged technology, media, and information skills as necessary skills that must be possessed in 21st-century learning.

The development of technology in education plays an essential role in implementing Education 4.0 [7]. Technology can help to support the teaching and learning process because learners can learn any information whenever and wherever they are, as well as active in the learning process [8]. With the development and efforts of ICT, transformational changes in Education 4.0 can be realized and continue to improve the quality of learning 
[5]. The development of technical communication is one of the important things to ensure the suitability of graduates in educational institutions [9].

The use of multimedia can allow students to involve themselves actively in the learning process due to the combination of entertainment and education that contribute to the new learning concept named edutainment [10]. Multimedia in e-learning can stimulate students' thinking process, create an exciting teaching atmosphere, and increase the reading skills among students [11]. The use of multimedia can help to improve the attitude of students $[11,12]$. Multimedia was not only can improve students' attitude, but also able to increase their interest in learning and improve their academic results [14].

Science is a subject that is studied by students ranging from elementary school to higher education in Malaysia. Through the learning of science education, learners can equip themselves with the skills and attitudes of scientists, as well as scientific natures, including facts, concepts, theories, and principles [15]. Although the Ministry of Education Malaysia had proposed and implemented remarkable strategies and plans in improving science education, yet the performance of Malaysian students in science was still fell behind in comparison to students in other countries. Based on the Trends in International Mathematics and Science Study (TIMSS), the performance of fourteen years old Malaysian students in science was found in a decreasing trend from the year 2003 to 2011. In terms of performances, the average scores of Malaysian students in science subjects were only 438 , as compared to the average score of 489 in other countries [16].

The conventional classroom is a teacher-centered teaching strategy where it involves only chalk, blackboard, and printed teaching materials. Teacher plays a considerable role in controlling all teaching processes, convey learning materials, and emphasizes only on factual knowledge [17]. Students in the conventional classroom are found more passive and always wait for an explanation from their teachers [18]. A lack of detailed discussion was observed between teachers and students in a conventional classroom [19]. Conventional teaching strategies hardly stimulate students' thinking skills, and show that students have a low attitude towards conventional teaching methods [20]. Students in conventional classes were found to pay more attention to taking notes rather than being involved in the learning process [21]. Along with digital technology in this era, multimedia had brought tremendous changes and benefits in the teaching and learning process.

The use of technology in teaching and learning processes had been proved that can increase self-achievement, intrinsic motivation, and extrinsic motivation of students in the classroom [22, 23]. Active multimedia-based learning can improve cognitive processes and enhance students' ability to absorb and assimilate knowledge [24]. Multimedia-based learning in the classroom can help develop an active and innovative learning environment where students in studies are found to be more motivated to learn [11].

\section{Objective Research}

This study aims to investigate the academic achievements of students towards science learning by using multimedia learning videos about reproductive topics in science subjects in junior high schools. The problem raised in this research is to find out the differences in the students' pre-test and post-test scores on the topic of reproduction of science subjects in conventional teaching and multimedia teaching. Based on the research problem, the hypothesis in the study includes:

HO1 There is no significant difference between the pre-test scores of students taught with conventional pedagogy and multimedia pedagogy in the reproduction topic of science subjects.

$\mathrm{HO} 2$ There is no significant difference between the post-test scores of students taught with conventional pedagogy and multimedia pedagogy in the reproduction topic of science subjects.

\section{Materials and Methods}

The method used in this research is descriptive. This study involved 40 junior high school students in Malaysia. Respondent is divided into two groups, namely conventional (control) and experimental (multimedia-based) groups. Both groups of students are taught by the same teacher. Lesson plans are prepared for both groups and ensure the same content is given to all respondents. Conventional groups are taught using science textbooks, and experimental groups are taught using multimedia learning videos. Pre-test and post-test are given to the experimental group and conventional groups to investigate students' academic achievement. The independent variable is the result of conventional and multimedia-based learning pre-tests. In contrast, the dependent variable is the difference in respondents' post-test results.

The achievement test in this study had fifteen multiple-choice questions with four items generated based on the syllabus from the topic of reproduction of natural science learning. Multiple-choice questions are the types of questions used to assess the level of teaching, level of knowledge to an evaluation in Bloom's Taxonomy. They are suitable for evaluating various types of questions [25]. After the implementation of the pre- and post-test, the scores were calculated respectively for each student. Normality test is carried out to determine the distribution of research data and data analysed by T-test at the $5 \%$ level. 


\section{Result}

\subsection{Normality Test}

Before the data analysis process, the data first undergo a Shapiro-Wilk test to identify whether the data has a normal distribution. The normality test shows the conventional group Pre-test with a P-value of 0.520 and the experimental group with a P-value of 0.345 . The normality test shows that the Post-test is the conventional group with a $\mathrm{P}$ value of 0.121 , and the experimental group is the P-value of 0.094 . Because the $p$-value for pre-test and post-test is greater than $0.05(\mathrm{p}>0.05)$, it can be said that the data has a normal distribution [25]. Parametric analysis was implemented in this study where the total score, arithmetic mean, standard deviation and t-test were used for comparison of data.

\subsection{Pre-test}

Student pre-test scores in conventional and experimental teaching are used to test hypothesis one. Independent t-test sample was used to test whether there were significant differences in pre-test scores between conventional teaching and experimental teaching. The results of the pre-test of the control and experimental respondents can be seen in Table 1.

Table 1. t-test summary on students' pre-test result in the conventional and experimental group

\begin{tabular}{cccccc}
\hline Group & Mean & $\begin{array}{c}\text { Standard } \\
\text { Deviation }\end{array}$ & $t$ & Df & Significant \\
\hline Conventional & 31.665 & 13.138 & & & \\
Experimental & 33.325 & 12.422 & -0.411 & 38 & 0.684 \\
\hline
\end{tabular}

Based on the result in Table 1, the null hypothesis is failed to be rejected as value $\mathrm{p}$ was higher than a significant level, $\alpha(p=0.684>0.05)$. The results show that there is no significant difference between conventional teaching pre-test scores and multimedia teaching pre-test scores in studying the subject matter of reproductive science. Also, it can be said that students in conventional and experimental teaching have the same level of knowledge before the study because the mean scores for the two teaching groups are almost the same.

\subsection{Post-test}

Student post-test scores in conventional and experimental teaching are used to test hypothesis two. Independent t-test samples were used to test whether there were significant differences in post-test scores between conventional teaching and experimental teaching. The results of the control and experimental respondents' post-test results can be seen in Table 2 .
Table 2. t-test summary on students' post-test result in the conventional and experimental group

\begin{tabular}{cccccc}
\hline Group & Mean & $\begin{array}{c}\text { Standard } \\
\text { Deviation }\end{array}$ & $t$ & Df & Significant \\
\hline Conventional & 50.335 & 12.332 & & & \\
Experimental & 70.995 & 12.295 & -5.306 & 38 & 0.000 \\
\hline
\end{tabular}

Based on the result in Table 2, the null hypothesis is being been rejected as value $\mathrm{p}$ was lower than a significant level, $\alpha(p=0.000<0.05)$. The results show that there is a significant difference between conventional teaching post-test scores and multimedia teaching in learning the topic of reproduction of science subjects. Also, we can conclude that the academic achievement of the experimental group is far better than the conventional group, as the mean scores of post-test results for the experimental group are 70.995, while mean scores of post-test results for the conventional group are only 50.335 . Hence, we can conclude that the teaching of the reproduction topic in science subjects is more effective in improving students' academic performance when multimedia-based pedagogy is applied in the classroom.

\section{Discussion}

The findings of this study show a parallel result with [26], that students who undergo multimedia learning get higher scores than the control group in learning. Previous research also revealed that the use of multimedia can increase nurses' pain knowledge and competency assessment [27]. Multimedia-based learning is effective in improving student performance [15]. The use of audio-visual instruction can improve the communication of ideas and concepts in science and is more effective in teaching students [28]. Effective multimedia learning media can improve communication and retention of learning content, as well as increase student attention and curiosity during learning [29]

This study is also in agreement with [30], which illustrated that the incorporation of multimedia-mediated content could improve students' learning achievement. Besides, the finding from the same study also found out that the students were observed more motivated and actively engaged themselves during the learning process. The study [31] also concluded that effective use of visual aids could stimulate thinking of students, improve learning environment as well as replace monotonous learning environment.

In light of finding that obtained from this study, the results showed that multimedia-based pedagogy is much more effective in developing mental models of students. The formation of the verbal model and pictorial model in the working memory allowed integration with students' activated prior knowledge and stored long-term memory knowledge [32]. Test results are given to the conventional pre-test group with a value of 31.665 and a post-test of 
50.335. Experimental group test results with a pre-test value of 33.325 and a post-test of 70.995 . The higher average scores obtained prove that a media-rich approach to learning can help students learn and increase their retention.

Apart from that, Individual differences in learning can be seen through learning with multimedia-based learning materials [33]. This statement can explain the finding that students with multimedia learning have higher average scores in academic performance. No doubt is saying that each student possesses a different learning style, and not all the students can learn similar content at the same pace. However, multimedia learning material provides greater flexibility for the students to control their own pace of learning as they have the freedom to slow down, speed up, reverse back, or pause the multimedia learning material. Also, multimedia-based learning materials can engage students' sensations into learning processes. Feeling, audition, vision, and mind of students are actively concentrated when multimedia is engaged in their learning process [34].

The finding of this study also showed that the student-centered learning approach was suitable for learning science subjects for secondary education. Students were found more active in engaging themselves in their learning and contribute to higher academic achievement in the post-test result. This approach had promoted more meaningful learning experiences for students in learning science subjects and can transform students to become pro-active and self-directed learners.

\section{Conclusions}

The use of multimedia elements in learning materials had much-improved students' learning experiences. Multimedia learning materials allow students to learn at their own pace and address their different senses. Through the learning with integration of multimedia-mediated content, students' learning achievement in the science subject was improved, and it had helped students to develop a better understanding of the science's concept and ideas.

Based on the finding of the study, the researcher would recommend those science teachers should implement multimedia-mediated content in teaching science subjects for secondary education. The conventional teaching approach should be substituted in order to curb the downward trend of science knowledge in our country. Furthermore, the educational technologist is urged to assist science teachers in developing multimedia teaching materials for science subjects that accommodate different learning styles of students in secondary education.

\section{Acknowledgements}

The author would like to thank Research Fund E15501,
Research Management Centre, UTHM for its support and fund of this research.

\section{REFERENCES}

[1] M. Ruhizan, M. Norazah, M. Bekri, A. Faizal, and A. Jamil, "Vocational Education Readiness in Malaysia On the Use Of E-Portfolios," J. Tech. Educ. Train. |, vol. 6, no. 1, pp. 57-71, 2014.

[2] K. M. Chuah, "Aplikasi Media Sosial dalam Pembelajaran Bahasa Inggeris: Persepsi Pelajar Universiti," Issues Lang. Stud., vol. 2, no. 1, May 2013, doi: 10.33736/ils.1680.2013.

[3] S. A. Nikou and A. A. Economides, "The impact of paper-based, computer-based and mobile-based self-assessment on students' science motivation and achievement," Comput. Human Behav., vol. 55, pp. 12411248, 2016, doi: 10.1016/j.chb.2015.09.025.

[4] P. Y. Chen and G. J. Hwang, "An Empirical Examination of The Effect of Self-Regulation and The Unified Theory of Acceptance and Use of Technology (UTAUT) Factors on The Online Learning Behavioural Intention of College Students," Asia Pacific J. Educ., vol. 39, no. 1, pp. 79-95, Jan. 2019, doi: 10.1080/02188791.2019.1575184.

[5] K. Shanmugam and B. Balakrishnan, "Kerangka Panduan Efektif Pengajaran Dan Pemudahcaraan (PdPc) Sains Menggunakan Information Communication Technology (ICT) di Sekolah Jenis Kebangsaan Tamil (SJK) (TAML)," Sains Humanika, vol. 10, no. 1, Dec. 2017, doi: 10.11113/sh.v10n1.1322.

[6] I. R. Katz, "ETS Research Finds College Students Fall Short in Demonstrating ICT Literacy," College and Research Libraries News, vol. 68, no. 1. Association of College and Research Libraries, pp. 35-37, 2007, doi: 10.5860/crln.68.1.7737.

[7] C. W. Anggraeni, "Promoting Education 4.0 in English for Survival Class: What are the Challenges?," Metathesis J. English Lang. Lit. Teach., vol. 2, no. 1, p. 12, May 2018, doi: 10.31002/metathesis.v2i1.676.

[8] A. Sadiyoko, "Industry 4.0: Ancaman, Tantangan atau Kesempatan? Sebuah Introspeksi Menyambut Kemajuan Teknologi Saat Ini," Oratio Dies XXIV FTI UNPAR , 2017.

[9] K. A. Jamaludin, N. Alias, D. DeWitt, and A. R. Abdul Razzaq, "Framework for Technical Communication Skills Content Development for Students in Malaysian Vocational Colleges: A Fuzzy Delphi Study," J. Tech. Educ. Train., vol. 11, no. 4, pp. 36-44, 2019, doi: 10.30880/jtet.2019.11.04.0 05 .

[10] J. Harun and Z. Tasir, Multimedia dalam Pendidikan. PTS Publication, 2003.

[11] A. R. Jamian, N. Hashim, and S. Othman, "Multimedia Interaktif Mempertingkatkan Pembelajaran Kemahiran Mambaca Murid-murid PROBIM," J. Pendidik. Bhs. Melayu, vol. 46, no. 2, 2012.

[12] K. C. Huff, "The comparison of mobile devices to computers for web-based assessments," Comput. Human Behav., vol. 
49, pp. 208-212, 2015, doi: 10.1016/j.chb.2015.03.008.

[13] M. Awang, A. Ahmad, and N. S. A. Talib, "Penggunaan Multimedia Dalam Pendidikan Sejarah Pada Abad Ke-21 Dan Hubungannya Dengan Minat Belajar Sejarah," $J$. Pemikir Pendidik., vol. 7, pp. 57-72, 2016.

[14] G. J. Hwang and H. F. Chang, "A formative assessment-based mobile learning approach to improving the learning attitudes and achievements of students," Comput. Educ., vol. 56, no. 4, pp. 1023-1031, 2011, doi: 10.1016/j.compedu.2010.12.002.

[15] O. Thomas, "Effectiveness of Animation and Multimedia Teaching on Students' Performance in Science Subjects," Br. J. Educ. Soc. Behav. Sci., 2014, doi: 10.9734/bjesbs/2014/3340.

[16] A. Schleicher, "PISA 2018 insights and interpretations," OECD Publ., 2019.

[17] D. V. S. Acca and R. V Aicwa, "Innovative Methods of Teaching I. Introduction II. Importance of Education:"

[18] M. A. Mulyana, N. Hanifah, and A. K. Jayadinata, "Penerapan Model Kooperatif Tipe Numbered Heads Together (NHT) Untuk Meningkatkan Hasil Belajar Siswa Pada Materi Kenampakan Alam Dan Sosial Budaya," $J$. Pena Ilm., vol. 1, no. 1, pp. 331-340, 2016, doi: 10.23819/pi.v1i1.3039.

[19] N. Aniza Ahmad and L. Nee Chua, "Technology and Higher Education: Using an E-Learning Tutorial as a Pedagogy for Innovation and Flexible Learning," Malaysian J. Distance Educ., vol. 17, no. 1, pp. 21-31, 2015.

[20] R. Phonguttha, S. Tayraukham, and P. Nuangchalerm, "Comparisons of mathematics achievement, attitude towards mathematics and analytical thinking between using the geometer's sketchpad program as media and conventional learning activities," in IMSCI 2008 - 2nd International Multi-Conference on Society, Cybernetics and Informatics, Proceedings, 2008, vol. 2, pp. 97-99, doi: $10.2139 /$ ssrn. 1285446 .

[21] D. Young and S. Seibenhener, "Preferred Teaching Strategies for Students in an Associate of Science Nursing Program," Teach. Learn. Nurs., 2018, doi: 10.1016/j.teln.2017.09.005.

[22] M. Granito and E. Chernobilsky, "The Effect of Technology on a Student' s Motivation and Knowledge Retention," NERA Conf. Proc., vol. 17, 2012.

[23] Y. P. Chua and Z. M. Don, "Effects of computer-based educational achievement test on test performance and test takers' motivation," Comput. Human Behav., vol. 29, no. 5, pp. 1889-1895, 2013, doi: 10.1016/j.chb.2013.03.008.

[24] W. Davies and K. Cormican, "An Analysis of the Use of Multimedia Technology in Computer Aided Design Training: Towards Effective Design Goals," Procedia Technol., vol. 9, pp. 200-208, 2013, doi: 10.1016/j.protcy.2013.12.022.

[25] S. Brookhart, "The new rules of measurement: What every psychologist and educator should know by Susan E. Embretson and Scott L. Hershberger, Mahwah, NJ: Lawrence Erlbaum Associates; 1999," Issues Educ., 1999, doi: 10.1016/s1080-9724(00)00034-3.

[26] O. Ercan, "The effects of multimedia learning material on students' academic achievement and attitudes towards science courses," J. Balt. Sci. Educ., 2014.

[27] T. L. Chu et al., "Multimedia-assisted instruction on pain assessment learning of new nurses: A quasi-experimental study," BMC Med. Educ., vol. 19, no. 1, p. 68, Mar. 2019, doi: 10.1186/s12909-019-1496-z.

[28] H. Samaras, T. Giouvanakis, D. Bousiou, and K. Tarabanis, "Towards a New Generation of Multimedia Learning Research," AACE Journal, vol. 14, no. 1, pp. 3-30, 2006.

[29] G. Syandri, "A Case Study on the Used of Visual Media in English Instructional Process at State Islamic Secondary School 1 Malang," IOSR J. Res. Method Educ. Ver. I, vol. 5, no. 4, pp. 2320-7388, 2015, doi: 10.9790/7388-05414656.

[30] F.-T. Leow and M. NEO, "Interactive Multimedia Learning: Innovating Classroom Education in A Malaysian University," TOJET Turkish Online J. Educ. Technol., vol. 13, no. 2, pp. 99-110, 2014.

[31] G. Shabiralyani, K. S. Hasan, N. Hamad, and N. Iqbal, "Impact of Visual Aids in Enhancing the Learning Process Case Research: District Dera Ghazi Khan.,"J. Educ. Pract. , vol. 6 , no. 19, 2015.

[32] R. E. Mayer, "Applying the Science of Learning: Evidence-Based Principles for the Design of Multimedia Instruction," Am. Psychol., 2008, doi: 10.1037/0003-066X.63.8.760.

[33] M. Betrancourt, "The Animation and Interactivity Principles in Multimedia Learning," in The Cambridge Handbook of Multimedia Learning, 2012.

[34] T. Vaughan, "Multimedia: Making It Work Eighth Edition," Tay Vaughan, 2006, doi: 10.2298/VSP0602169S. 